\title{
イオン液体界面研究の進歩と展開
}

\author{
大野弘幸・一川尚広・河野雄樹 \\ 東京農工大学大学院工学研究院 機能イオン液体研究センター \\ 正 184-8588 東京都小金井市中町 2 丁目 24-16 \\ （2012 年 12 月 11 日受付；2012 年 12 月 30 日揭載決定）
}

\section{Progress and Developments of Researches on Interface Concerning Ionic Liquids}

\author{
Hiroyuki OHNo, Takahiro IchIKAwa and Yuki Konno \\ Functional Ionic Liquid Laboratories, Graduate School of Engineering, \\ Tokyo University of Agriculture and Technology, 2-24-16 Naka-cho, Koganei, Tokyo 184-8588
}

(Received December 11, 2012 ; Accepted December 30, 2012)

\begin{abstract}
It is quite important to analyze and design interface between ionic liquid and other materials due to further development of functional interface. In the present study, physicochemical properties of mixtures containing ionic liquids are discussed. In the former part, interests are focused on the dynamic phase change of ionic liquid/water mixtures. Some ionic liquids show lower critical solution temperature type phase change after mixing with water. Component ions required for the realization of this type of phase change are proposed related to the water content. In the latter part, dimension control of ionic liquids is summarized considering the marriage of liquid crystals and ionic liquids. Through these results, importance of interface concerning ionic liquids has been mentioned.
\end{abstract}

KEYWORDS : ionic liquid, interface, phase change, liquid crystal

\section{1.は じめに}

従来から汎用されている分子性液体と大きく異なる特 徵を持つイオン液体は, 多彩多様なイオンから作ること ができる。特に多彩な有機イオンの選択により幅広い溶 液物性が発現されることもあり, 様々な分野で研究され るようになってきた。特徴ある液体として, 均一液体系 の研究から, 各種界面の研究まで幅広く展開されてい る。本誌でも 2007 年に特集が組まれているが, それ以 降の研究の展開も著しく, 新たに特集が組まれることに なった。今回の特集ではイオン液体が関与する様々な界 面の研究が紹介されるであろう。我々は各種機能イオン 液体そのものの研究もさることながら, イオン液体と他 の物質の混合系についても興味を持っている。したがっ て，それらの間で形成される界面にも関心がある。ここ ではイオン液体と水の混合系の動的な相状態の変化と, イオン液体を次元制御して液晶特性を導入した系に関す

E-mail : ohnoh@cc.tuat.ac.jp
る物理化学とその応用展開について最新の結果を紹介 し，機能界面の制御にまで言及したい。

\section{2. イオン液体と水の界面}

イオン液体は“塩”であるから, 水との親和性はよい と一般的には考えられている。しかし, 中には水と混和 せず, 液/液二相分離を示すものも多い。これらはそれ ぞれの液相の協奏的な利用につながるため, 興味を持た れるようになってきているとともに, 研究成果が増えて きている。また, それらの液/液二相の界面挙動が物質 の抽出, 分離, 移動, 保護などに関連するため, 将来は 積極的に利用されるようになると予想される。ここで は, 水と相分離するイオン液体が関与する界面の形成と 制御について報告する。

\section{1 水と相分離するイオン液体}

イオン液体の構成イオンを適切にデザインすると，粘 性や極性, 疎水性などの物理化学的性質が大きく異なる 液体が得られる。しかし, イオンのデザインのみで特定 の物性を持つイオン液体を得ることは汎用の戦略とはな 
り難い。一方，単にイオン液体と他の分子性液体を均一 に混合すると，その溶液物性は連続的に変化する。イオ ン液体はイオンのみから成ることを特徵としてきたた め, 分子性溶媒を加えてしまっては難揮発性, 高イオン 密度などイオン液体固有の性質が損なわれると思われて きた。事実，これまでは水などの分子性液体は不純物と して考えられ，いかにこれらを排除するかに努力が払わ れていた。しかし，積極的にイオン液体と分子性溶媒を 混合してその挙動を見ると，イオン液体単独では見られ なかった新しい性質が次第に認められるようになってき た。

イオン液体/分子性溶媒混合系の中で最も広く研究さ れているのは，イオン液体/水混合系であろう。多方面 への応用を意識すれば，イオン液体と組み合わせるパー トナーは水であることが望ましく，特にバイオサイエン 久分野におけるイオン液体/水混合系の発展はめざまし い。さらに, イオン液体と水の親和性を適切に制御し て，互いに混じり合わない液/液二相界面を形成させる ことは，応用展開をも拡げるものである。

\section{2 水との相挙動を制御できるイオン液体}

構成イオンにビス（トリフルオロメタンスルホニル） イミド $\left(\left[\mathrm{Tf}_{2} \mathrm{~N}\right]^{-}\right)$やへキサフルオロホスフェート $\left(\mathrm{PF}_{6}{ }^{-}\right)$などフッ素原子を含むアニオンを用いると, 水 と相分離する疎水性イオン液体が得られる ${ }^{1,2)}$ 。一方, 水と任意の割合で混和する親水性イオン液体であって も，塩析効果の高い無機塩を適切に混合すれば，含水イ オン液体相と無機塩水溶液相とに分離する ${ }^{3)}$ 。これらイ オン液体/水二相系は安定で, 常に相分離した状態を保 持するため取り扱いやすく, その界面状態解析から化合 物の溶解性制御に至るまで多方面で展開されている。従 来までのイオン液体/水二相系は，いわば“静的な相分 離”であると言え，相分離状態は外部の環境変化に依存 しない。これに対して，温度変化などの外部因子により 相挙動を “動的に” 制御できるイオン液体/水混二相系 が存在する。著者らの研究グループでは近年，僅かな温 度変化で相溶状態と相分離状態を可逆的に制御できるイ オン液体/水混合系を報告した ${ }^{4,5)}$ 。たとえば，Fig. 1 は テトラブチルホスホニウムカチオン $\left(\left[\mathrm{P}_{4444}\right]^{+}\right)$とトリ フルオロ酢酸アニオン $\left(\mathrm{CF}_{3} \mathrm{COO}^{-}\right)$からなるイオン液 体を $35 \mathrm{wt} \%$ となるよう水と混合すると， $34^{\circ} \mathrm{C}$ では相分 離し，温度を $5{ }^{\circ} \mathrm{C}$ 下げると均一な溶液となり，再び $34^{\circ} \mathrm{C}$ にすると相分離した状態に戻る様子を示している。加熱 すると溶解度が増すという一般的な挙動とは異なり，冷 却により相溶する下限臨界溶解温度 (lower critical solution temperature; LCST) 型の相挙動を示すイオン液体/ 水混合系は著者らの研究室ではじめて見いだされた。こ

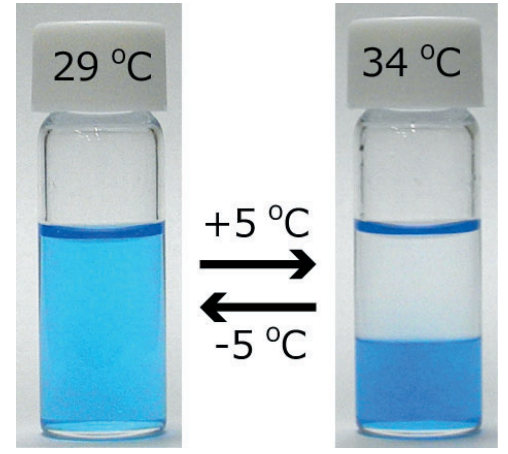

Fig. 1. (color online). An example of ionic liquid-water mixtures undergoing temperature-sensitive phase change between homogeneous phase and liquid-liquid biphase. The ionic liquid bottom phase was colored by Coomassie Brilliant Blue.

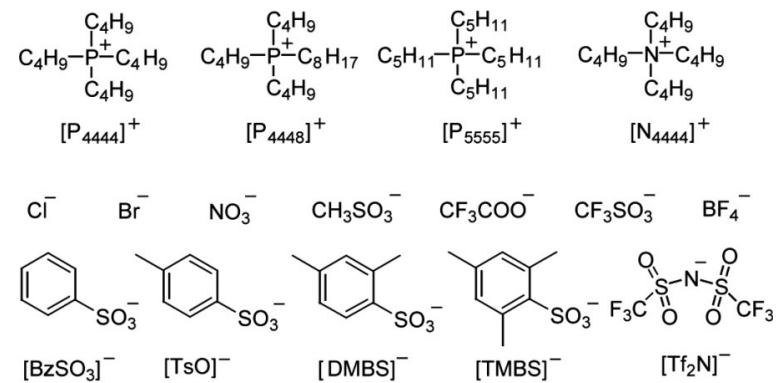

Fig. 2. Component ions of ionic liquids with different hydrophilicity.

の相変化は何度でも繰り返し可能であり, 構成イオンに 応じて室温付近を含む幅広い温度範囲で相溶・相分離を 制御できる。水と LCST 型の相挙動を示すイオン液体 は, アミノ酸誘導体塩 ${ }^{4}$ やジカルボン酸塩 ${ }^{5}$ など僅かな イオン種が報告されているだけであり，相挙動に求めら れる因子は整理されていなかった。Fig. 1 から明らかな ように, 相溶・相分離の過程でイオン液体相の含水率, 換言すれば親水性が，大きく変化していることがわか る。そこで，親水性の異なるイオンから成るイオン液体 を多種作製して，水との相挙動を解析し，水と LCST 挙 動を示すイオン液体の探索，および相挙動に求められる 因子を検討した。検討に用いたイオン種は，イオン液体 の構成イオンとして一般的に用いられるものを含め, カ チオン 4 種，アニオン 12 種である（Fig. 2)。作製した イオン液体/水混合系の相挙動は, 構成イオン種により 大きく異なり，その相挙動を個々のイオン種で並べると Table 1 のようになった6)。たとえば， $\left[\mathrm{P}_{4444}\right]^{+}$をカチ才 ンに有するイオン液体に焦点を当てると, 親水性の高い クロライド $\left(\mathrm{Cl}^{-}\right)$やメタンスルホネート $\left(\mathrm{CH}_{3} \mathrm{SO}_{3}{ }^{-}\right)$ 
Highly temperature-sensitive phase transition of ionic liquid (IL)/water mixtures

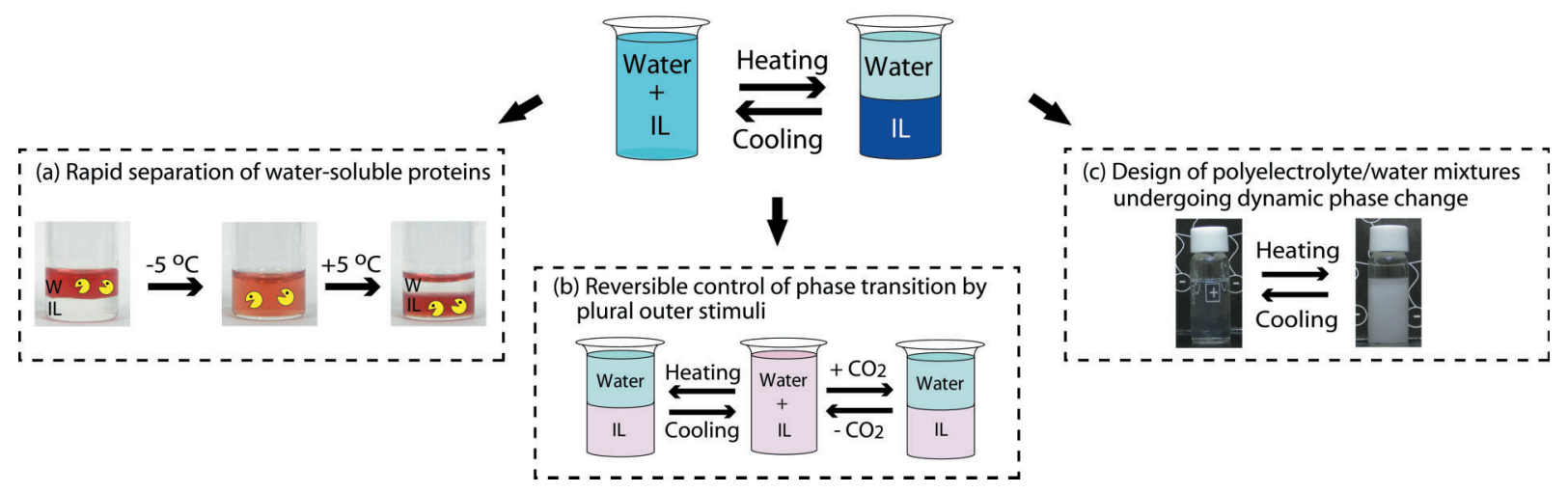

Fig. 3. (color online). Application of temperature-sensitive phase transition of ionic liquid/water mixtures.

Table 1. Phase behavior of ionic liquids composed of the individual cation and anions after mixing with equal weight of water.

\begin{tabular}{lcccc}
\hline & {$\left[\mathrm{P}_{5555}\right]^{+}$} & {$\left[\mathrm{P}_{4448}\right]^{+}$} & {$\left[\mathrm{P}_{4444}\right]^{+}$} & {$\left[\mathrm{N}_{4444}\right]^{+}$} \\
\hline$\left[\mathrm{Tf}_{2} \mathrm{~N}\right]^{-}$ & $\times$ & $\times$ & $\times$ & $\times$ \\
$\mathrm{BF}_{4}{ }^{-}$ & $\times$ & $\times$ & $\times$ & $\times$ \\
$\mathrm{CF}_{3} \mathrm{SO}_{3}{ }^{-}$ & $\times$ & $\times$ & $\times$ & $\times$ \\
{$\left[\mathrm{TMBS}^{-}\right.$} & $\times$ & $\times$ & LCST & LCST \\
$\mathrm{CF}_{3} \mathrm{COO}^{-}$ & $\times$ & $\times$ & LCST & $\bigcirc$ \\
{$[\mathrm{DMBS}]^{-}$} & $\times$ & $\times$ & LCST & $\bigcirc$ \\
{$\left[\mathrm{TsO}^{-}\right.$} & $\times$ & $\times$ & LCST & $\bigcirc$ \\
{$\left[\mathrm{BzSO}_{3}\right]^{-}$} & $\times$ & $\times$ & $\bigcirc$ & $\bigcirc$ \\
$\mathrm{NO}_{3}{ }^{-}$ & $\times$ & $\times$ & $\bigcirc$ & $\bigcirc$ \\
$\mathrm{Br}^{-}$ & $\times$ & LCST & $\bigcirc$ & $\bigcirc$ \\
$\mathrm{Cl}^{-}$ & $\times$ & $\bigcirc$ & $\bigcirc$ & $\bigcirc$ \\
$\mathrm{CH}_{3} \mathrm{SO}_{3}{ }^{-}$ & $\bigcirc$ & $\bigcirc$ & $\bigcirc$ & $\bigcirc$ \\
\hline $\mathrm{Chydr}_{4}$ & & $\times$ & & $\bigcirc$
\end{tabular}

: hydrophilic ionic liquid, $\times$ : hydrophobic ionic liquid

をアニオンに持つ塩は水と混和し (表中○印), 親水性

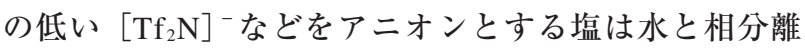
した (同 $\times$ 印)。一方, $p$-トルエンスルホネートアニオ ン $\left([\mathrm{TsO}]^{-}\right)$およびその誘導体, さらに $\mathrm{CF}_{3} \mathrm{COO}^{-}$を 持つ塩を水と混合すると, LCST 型の相挙動を示した。 次いでカチオンを $\left[\mathrm{P}_{4444]}\right]^{+}$よりも親水性の低いトリブ チルオクチルホスホニウム $\left(\left[\mathrm{P}_{4448}\right]^{+}\right)$を用いてイオン 液体を形成させると，ほとんどの種類のイオン液体が水 と常に相分離し，ブロマイド $\left(\mathrm{Br}^{-}\right)$をアニオンに持つ イオン液体のみが水と LCST 型の相挙動を示した。これ らの結果から, 我々は「構成イオンの親水性の総和が相 挙動を支配する因子であり, 親水性がある一定の範囲に あるイオン液体が LCST 挙動を示す」と予測した。これ を証明するため, 水と相分離したイオン液体の親水性を 表わす具体的な指標を求めた。まず，相分離後のイオン
液体相の含水率が構成イオン種の親水性により大きく異 なることに着目し, 相分離後のイオン液体 1 イオンペア に対する水分子の数 $\left(m_{\text {water }}\right)$ を含水率から算出した。 その結果, LCST 挙動を示すイオン液体は水と常に相分 離するイオン液体よりも高い $m_{\text {water }}$ を示し, 相分離後も 多くの水分子を保持していることが特徴であった。そこ で，60年における $m_{\text {water }}$ を hydrophilicity index (HI) と定 義して水と相分離する多くのイオン液体の HI を算出し た。得られた $\mathrm{HI}$ 值と相挙動の関係を検討した結果，HI が 6 以下のイオン液体は水と常に相分離した状態が安定 であり, HI が 7 以上のイオン液体は水と LCST 挙動を 示すことを見いだした。この知見を応用すると, 各イオ ンを親水性の順に並べることができた。また，新たに水 と LCST 型の相挙動を示すいくつかのイオン液体を見い だすことができた ${ }^{6,7)}$

水と LCST 型の相挙動を示すイオン液体に求められる 因子が整理できたため，この知見をもとに様々な展開に つなげた。Fig. 3 に我々が検討したイオン液体/水混合 系の応用例をまとめた。例えば，僅かな温度変化で相 溶・相分離する性質を利用し, いくつかの水溶性夕ンパ ク質を水相からイオン液体相へ瞬時に分離することに成 功した (Fig. 3 (a) $)^{8)}$ 。さらに, タンパク質の種類によ りイオン液体相への移動率が異なることを利用して, 混 合系から特定タンパク質のみを分離することもでき た ${ }^{8)}$ 。上述の温度変化による相転移に加え, 構成イオン 種によっては $\mathrm{CO}_{2}$ ガスの添加・除去など複数種の因子 で可逆的に水との相溶・相分離を制御できることも明ら かになった（Fig.3（b））帛。さらに, 僅かな温度差で親 水性が変化するイオン液体の特徵を高分子一賦与するこ とを目指し, 水と LCST 型の相挙動を示すイオン液体モ ノマーを新規に作製し，その重合体がモノマーと同様に 
水中で LCST 型の相挙動を示すことを見いだした（Fig. $3(\mathrm{c}))^{10)}$ 。このように, イオン液体/水混合系の動的な 相転移挙動は, 多方面への展開につながる重要な分野で あり, 僅かな温度変化を含む種々の外部因子を認識する 機能界面を与えるものと期待している ${ }^{11}$ 。

\section{3. イオン液体の次元制御}

イオン液体は分子性液体と異なる特徴を持った均一な 液体として認識され，幅広い分野で利用が検討されてい るが, この等方性液体の次元制御を行うと, 様々な機能 展開が期待できる ${ }^{12)}$ 。イオン液体に自己組織化能を導入 すれば, 集合体由来の機能を示す新しいイオン性ナノ材 料ができ上がる。このような視点から，イオン液体と液 晶を組み合わせるというアプローチは機能物質創成に非 常に有用であると言える。イオン液体を化学修飾して液 晶性を示すようにすることは容易である。これらは液晶 の観点からすると, イオン性の骨格を有する液晶分子と して分類でき，イオン性液晶と総称されている ${ }^{13)}$ 。イオ ン性液晶の研究は古くから行われている。たとえば, 長 鎖アルキル基を有するピリジニウム塩やイミダゾリウム 塩がスメクチック液晶相を発現することが報告されてい $3^{14,15)}$ 。我々は, 液晶性を示すイオン液体を積極的にデ ザインすることで, より多様なナノ構造を形成する自己 組織性イオン液体の構築について研究を進めている ${ }^{16)}$ 。 近年では, さらなる展開として, カチオンとアニオンが 共有結合で結ばれた有機塩 (zwitterion) の組織化も行 っている。本節ではイオン液体や zwitterion をベースと した様々に次元制御した液晶分子の自己組織化構造 （Fig. 4）とその機能について解説する。

\section{1 イオン液体の組織化}

非相溶の骨格からなるブロック分子はナノスケールで

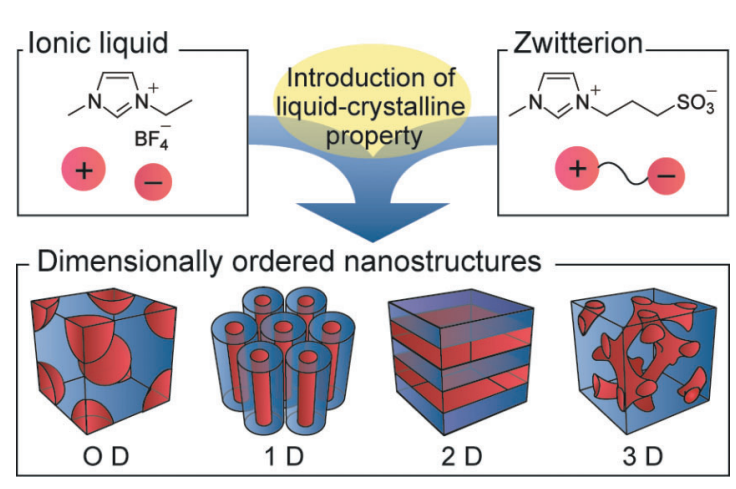

Fig. 4. (color online). Strategy for the dimensional control of ionic liquids. Introduction of liquid-crystalline properties into ionic liquids or zwitterions provides a new class of nanostructured ionic materials.
の相分離を駆動力として様々な次元構造を形成する。た とえば，レイヤー状のスメクチック相やシリンダー状の カラムナー相が代表的なナノ相分離構造である（Fig. 4)。目的の集合構造へと分子を自己配列させるために は, 分子の形や相互作用をいかに制御するかが鍵とな る。イオン液体の二次元レイヤー状組織化を目指し, 長 鎖アルキル基をアニオンに導入し，イミダゾリウムカチ オンと組み合わせた塩 1 (Fig. 5) が設計されている ${ }^{17) 。 ~}$ イオン性のイミダゾリウム塩部位と疎イオン性のアルキ ル鎖部位がナノ相分離し, レイヤー状のスメクチック液 晶相を発現する。イオン性のレイヤーに沿った方向に効 率的にイオンが拡散することができるため, 二次元イオ ン伝導体として機能する。

イミダゾールとある種の酸を複合化させるとプロトン 性イオン液体が得られる ${ }^{18,19)}$ 。イミダゾールはプロトン ドナー部位とアクセプター部位を有しているため, この プロトン性イオン液体にイミダゾールを適切に添加して 組織化することができれば，ホッピング伝導によりプロ トンを輸送する材料の開発に繋がる。イミダゾール環 2 位に長鎖アルキル基を導入した化合物 2a および $2 \mathrm{a}$ に等 モルの $\mathrm{HBF}_{4}$ を加えた 2b が設計されている (Fig. 6) ${ }^{20)}$ 。 2a/2bをモル比 1：9 複合化したサンプルはスメクチ

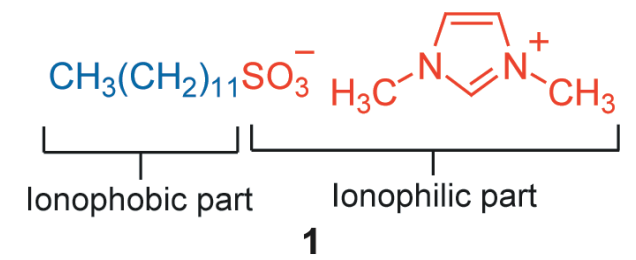

Fig. 5. (color online). Structure of imidazolium salt $\mathbf{1}$ exhibiting a smectic liquid-crystalline phase.

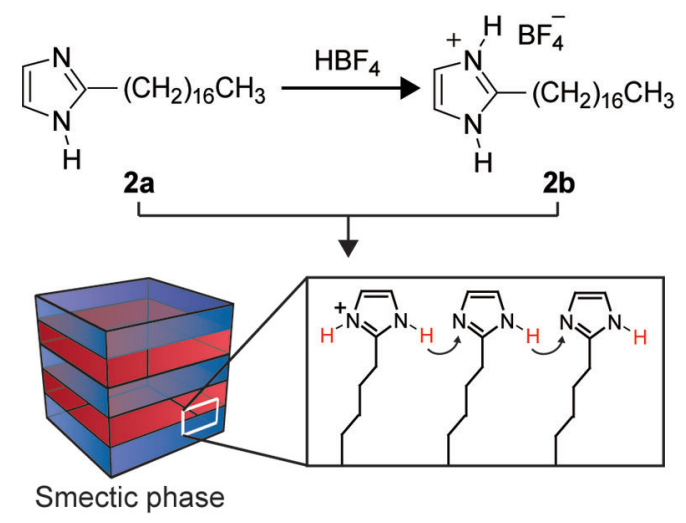

Fig. 6. (color online). Molecular structure of imidazole derivative 2a having a long alkyl chain and imidazolium salt $\mathbf{2 b}$ prepared by the neutralization of $\mathbf{2} \mathbf{a}$ and $\mathrm{HBF}_{4}$. 
ック液晶相を示し，レイヤー方向に効率的にプロトンを 伝導する材料として機能する。

これらのイオン性液晶が形成するナノ相分離構造の次 元性は, イオン性ドメインと非イオン性ドメインの界面 が形成する界面曲率によって支配される。言い換えれ ば，この曲率を制御することで多様なナノ相分離構造を デザインすることが可能となる。イオン液体をチャンネ ル状に組織する手法として複数本の長鎖アルキル基をイ オン液体に導入するアプローチが有用である。たとえ ば，長鎖アルキル基を三本有するイミダゾリウム塩 3 は ヘキサゴナルカラムナー相を発現し, 一次元的なイオン 性チャンネルを形成する（Fig.7 (a) $)^{21)}$ 。このカラムナ 一液晶に対して配向制御を施すと, 一次元イオン伝導体 として機能する。一方, 長鎖アルキル基を三本有する類 似のアンモニウム塩 4 は三次元的なイオン性チャンネル を有する双連続キュービック相を発現する（Fig.7 (b) $)^{22)}$ 。三次元的な周期構造を有する双連続キュービッ ク液晶はドメイン界面においてもチャンネルの連続性を 保つことができる。そのため, 配向制御不要な材料とし ての応用が強く期待されている。これらの分子に重合基 を導入し，液晶状態にたもったままその場重合すること によってナノ構造を固定化する展開も達成されてい る $^{23,24)}$ 。

このように, イオン液体を適切に化学修飾することで 様々な次元性のナノ構造状態として組織化できるように なる。また, 適切にデザインされた両親媒性分子とイオ ン液体の組織化を利用することでも同様の次元制御が害 現できる。詳細は原著論文を参照されたい ${ }^{25,26) 。 ~}$

\section{2 Zwitterion の組織化}

我々の研究室では機能性有機塩のさらなる展開として, カチオンとアニオンが共有結合で結ばれた zwitterionの (a)

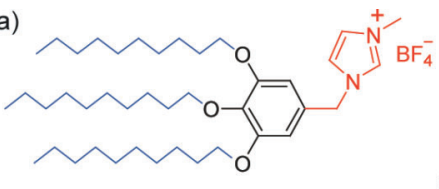

3

(b)

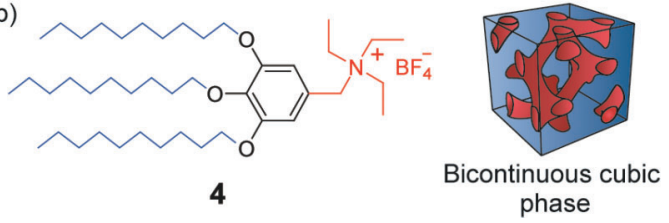

Fig. 7. (color online). Molecular structure of: (a) wedgeshaped imidazolium salt $\mathbf{3}$ exhibiting a hexagonal columnar phase; (b) wedge-shaped ammonium salt $\mathbf{4}$ exhibiting a bicontinuous cubic phase.
応用について研究を行っている ${ }^{27)}$ 。一般に zwitterion は イオンの自由度が制限されているため融点が高く, 結晶 状態を形成するが， $\left[\mathrm{Tf}_{2} \mathrm{~N}\right]^{-}$- のようなソフトなアニオン を有する酸やリチウム塩と混合するとガラス転移温度が 室温以下となり，液体状態を形成するようになる（Fig. 8) ${ }^{27,28)}$ 。これは zwitterion のカチオンと $\left[\mathrm{Tf}_{2} \mathrm{~N}\right]^{-}$が優先 的に相互作用し，イオン液体様のイオンペアを形成する ためであると考えられる。したがって，これらの zwitterion のガラス転移温度を下げたまま組織化することが できれば，通常のイオン性液晶では発現しえない物性や 機能を示す材料への展開が期待できる。

両親媒性 zwitterion として長鎖アルキル基を有するホ スホニウム塩 5 が設計・合成されている $(\text { Fig. 9 })^{29)}$ 。こ

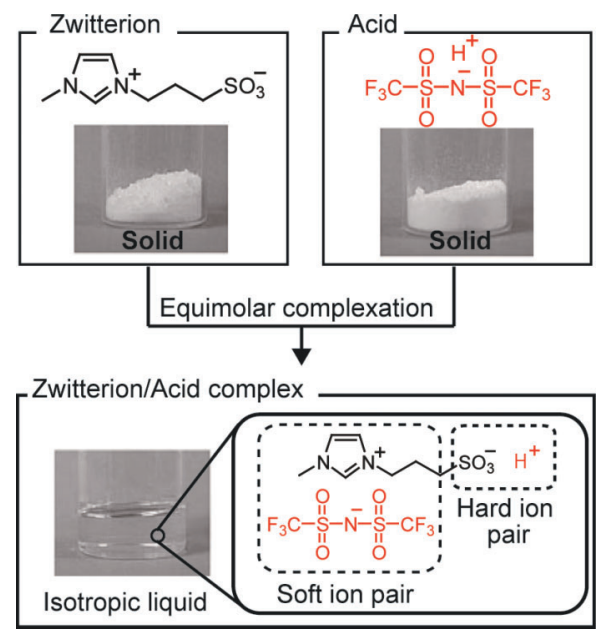

Fig. 8. (color online). Structure of an imidazolium-based zwitterion and $\mathrm{HTf}_{2} \mathrm{~N}$. An equimolar mixture of these two components forms an isotropic liquid.

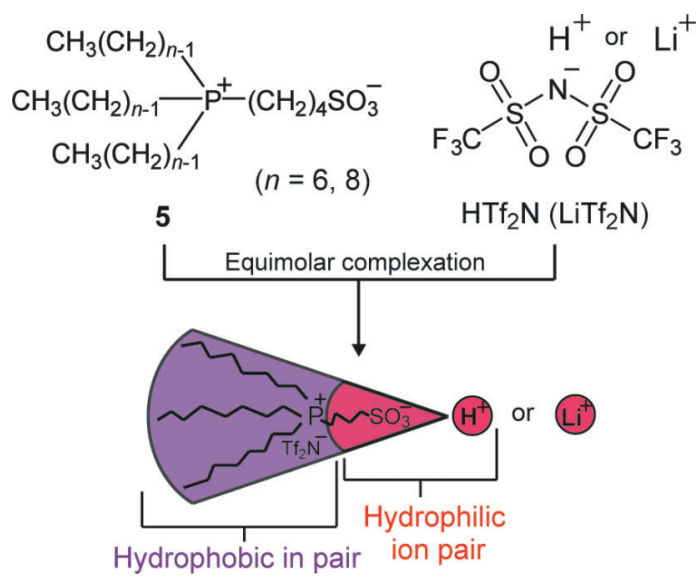

Fig. 9. (color online). Phosphonium-based zwitterion 5 and $\mathrm{HTf}_{2} \mathrm{~N}$ (or $\operatorname{LiTf}_{2} \mathrm{~N}$ ). An equimolar mixture of these two components forms hydrophilic and hydrophobic ion pairs. 
の分子と等モルの $\mathrm{HTf}_{2} \mathrm{~N}$ を複合化すると, 水の存在下 においてへキサゴナルカラムナー液晶相を発現する ${ }^{29)}$ 。 液晶状態においては，疎水的なアルキル鎖ドメインが親 水的な一次元イオンチャンネルを取り囲んだような界面 構造を形成していると考えられる。この一次元チャンネ ルを通じてプロトンを輸送することができるため，異方 的プロトン伝導場として機能する。

Zwitterion はカチオンとアニオンが連結されているた め, 他のイオンが多数存在していてもトポロジカルには イオンペアを保つ。このような特徵をうまく活用できれ ば，イオン液体の重要なパートナーとして zwitterion は 有用である。たとえば，zwitterionを用いたイオン液体 のゲル化 ${ }^{30)}$ やイオン液体中の含水率のコントロール ${ }^{31)}$ どが達成されている。また, 両親媒性 zwitterion とイオ ン液体を組み合わせることでユニークな液晶材料の開発 にも成功している ${ }^{32}$ 。 Z Zwitterion 5/ $\mathrm{LiTf}_{2} \mathrm{~N}$ 等モル複合体 に親水性のイオン液体を添加したところ, 二成分の割合 に応じてナノ相分離液晶構造 (ミセルキュービック構造 やカラムナー構造）を形成した。ナノ相分離構造の各ド メインは親水性イオン液体ドメインおよび疎水性イオン 液体ドメインから成り，このような系はナノ二相系イオ ン液体システムとしての展開が期待される。

Zwitterion/ $\mathrm{HTf}_{2} \mathrm{~N}$ 複合体をチャンネル状ではなく，そ れぞれの相が連続しており，しかも互いに相溶しないミ クロ相分離状態を形成できれば，機能性界面の開発とし て興味深い。特に, 双連続キュービック液晶が形成する三 次元極小界面（gyroid 極小界面）状に zwitterion $/ \mathrm{HTf}_{2} \mathrm{~N}$ 複合体を組織化することができれば，新しい機能性界面 の構築に繋がる。このような分子集合体の作成を目指 し, 多様な両親媒性 zwitterion を設計・合成し, それら の液晶性を検討したところ，長鎖アルキル基を有するピ リジニウム塩 6 が目的の双連続キュービック液晶相を発 現することを見いだした $(\text { Fig. 10 })^{33)}$ 。このピリジニウ 厶塩 6 は単独ではレイヤー状のスメクチック液晶相を形 成するが, $\mathrm{HTf}_{2} \mathrm{~N}$ の添加に伴い双連続キュービック相を 発現する。ソフトな $\left[\mathrm{Tf}_{2} \mathrm{~N}\right]^{-}$とピリジニウムカチオン の優先的なイオンペア形成が，このような集合構造の変 化を誘起していると考えられる。

この双連続キュービック液晶構造の模式図を Fig. 10 に示す。親イオン性部位（zwitterion 部位および $\mathrm{HTf}_{2} \mathrm{~N}$ ) が三次元的な gyroid 界面上に組織化し，疎イオン性の アルキル鎖が三次元的に連結したチャンネル状に組織化 した構造を有している。この gyroid 界面は三次元的に 連続しているため，液晶ドメインの配向制御を行わなく てもマクロに連続的した界面を形成する。この液晶材料 に少量の水を添加すると水分子が gyroid 界面に沿って

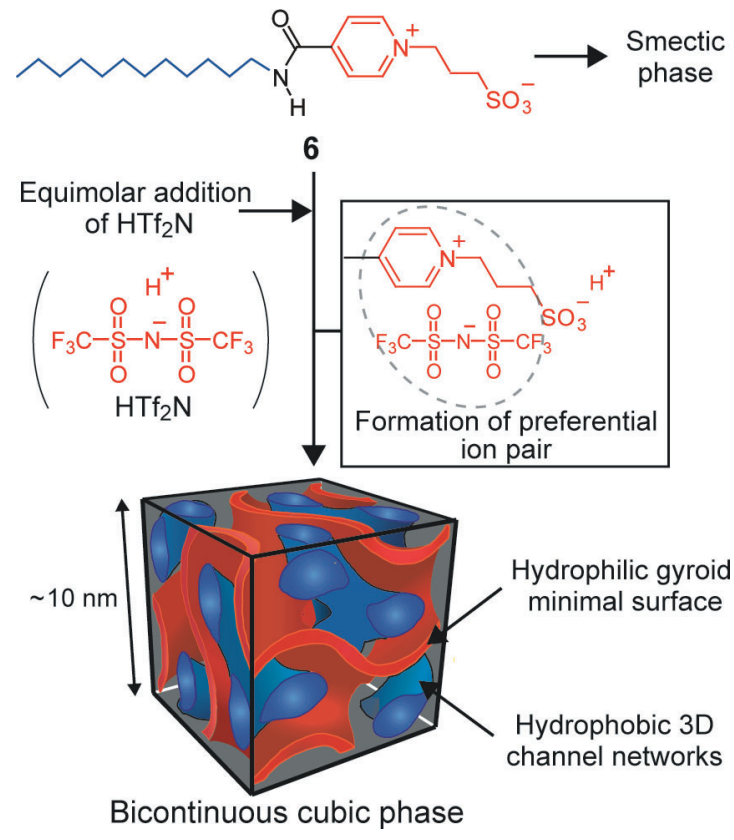

Fig. 10. (color online). Pyridinium-based zwitterion 6 coorganized with $\mathrm{HTf}_{2} \mathrm{~N}$ into a bicontinuous cubic phase having a three-dimensionally continuous hydrophilic gyroid minimal surface.

水素結合ネットワークを形成し, 効率的なプロトン伝導 性界面を生み出す。また，連続したミク口相分離構造 は, 界面の総面積がきわめて大きくなるため, 液/液界 面での動的な反応を利用する科学に大きく寄与するもの と期待される。

\section{3 イオン液体の組織化の今後の展開}

イオン液体や zwitterion を組織化することで, イオン 液体単独では決して達成しえない機能の発現に繋がる界 面構造を提供できることを明らかにしてきた。機能と分 子集合構造には密接な関係があり，分子のデザイン次第 でその機能や応用展開は無限の広がりを見せるであろ う。今後, これらのイオン性液晶が形成するナノ構造の 次元性や界面構造を制御することにより，化学分野のみ ならず, 電気化学 ${ }^{16)}$ から材料工学, さらには生命工学の 分野でも展開ができるようになり，高性能かつ新機能を 有するナノ材料の基幹戦略として期待される。

\section{4.お わりに}

イオン液体を成分とする混合系で様々な界面を形成で きることを示した。水と混合したときに形成される界面 を動的に制御できるイオン液体の種類を大幅に増やす努 力も, いくつかの応用に結実した。一方で，イオン液体 の次元制御を通じ，ミクロ〜ナノレベルで構造を設計す ることもできるようになってきた。今後はこれらの界面 
の特性を深く解析するとともに，様々な応用展開につな

げていきたい。

\section{謝辞}

本稿で紹介した研究は日本学術振興会からの科学研究 費補助金（No. 21225007，No. 23750147）によって推進 された。ここに謝意を表す。

\section{文献}

1) P. Bonhôte, A.-P. Dias, N. Papageorgiou, K. Kalyanasundaram and M. Grätzel : Inorg. Chem. 35, 1168 (1996).

2) J.G. Huddleston, A.E. Visser, W.M. Reichert, H.D. Willauer, G.A. Broker and R.D. Rogers : Green Chem. 3, 156 (2001)

3) K.E. Gutowski, G.A. Broker, H.D. Willauer, J.G. Huddleston, R.P. Swatloski, J.D. Holbrey and R.D. Rogers : J. Am. Chem. Soc. 125, 6632 (2003).

4) K. Fukumoto and H. Ohno : Angew. Chem., Int. Ed. 46, 1852 (2007).

5) Y. Fukaya, K. Sekikawa, K. Murata, N. Nakamura and H. Ohno : Chem. Commun., 3089 (2007).

6) Y. Kohno, H. Arai, S. Saita and H. Ohno : Aust. J. Chem. 64, 1560 (2011).

7) Y. Kohno and H. Ohno : Phys. Chem. Chem. Phys. 14, 5063 (2012).

8) Y. Kohno, S. Saita, K. Murata, N. Nakamura and H. Ohno : Polym. Chem. 2, 862 (2011).

9) Y. Kohno, H. Arai and H. Ohno: Chem. Commun. 47, 4772 (2011).

10) Y. Kohno and H. Ohno : Aust. J. Chem. 65, 9 (2012).

11) Y. Kohno and H. Ohno: Chem. Commun. 48, 7119 (2012).

12) 向井知大, 吉尾正史, 加藤隆史, 大野弘幸: 未来材料 6, 2 (2006).

13) K. Binnemans : Chem. Rev. 105, 4148 (2005).

14) G.A. Knight and B.D. Shaw : J. Chem. Soc., 682 (1938).

15) C.M. Gordon, J.D. Holbrey, A.R. Kennedy and K.R.
Seddon : J. Mater. Chem. 8, 2627 (1998).

16) H. Ohno (Ed.) : "Electrochemical Aspects of Ionic Liquids" (Wiley, 2nd edn, 2011).

17) T. Mukai, M. Yoshio, T. Kato and H. Ohno : Chem. Lett. 33, 1630 (2004).

18) M. Hirao, H. Sugimoto and H. Ohno : J. Electrochemical Soc. 147, 4168 (2000).

19) Md. A.B.H. Susan, A. Noda, S. Mitsushima and M. Watanabe : Chem. Commun., 938 (2003).

20) T. Mukai, M. Yoshio, T. Kato, M. Yoshizawa-Fujita and H. Ohno : Electrochemistry 73, 623 (2005).

21) M. Yoshio, T. Mukai, H. Ohno and T. Kato: J. Am. Chem. Soc. 126, 994 (2004).

22) T. Ichikawa, M. Yoshio, A. Hamasaki, T. Mukai, H. Ohno and T. Kato: J. Am. Chem. Soc. 129, 10662 (2007).

23) M. Yoshio, T. Kagata, K. Hoshino, T. Mukai, H. Ohno and T. Kato: J. Am. Chem. Soc. 128, 5570 (2006).

24) T. Ichikawa, M. Yoshio, A. Hamasaki, J. Kagimoto, H. Ohno and T. Kato: J. Am. Chem. Soc. 133, 2163 (2011).

25) H. Shimura, M. Yoshio, K. Hoshino, T. Mukai, H. Ohno and T. Kato: J. Am. Chem. Soc. 130, 1759 (2008).

26) T. Ichikawa, M. Yoshio, S. Taguchi, J. Kagimoto, H. Ohno and T. Kato: Chem. Sci. 3, 2001 (2012).

27) M. Yoshizawa, M. Hirao, K. Ito-Akita and H. Ohno : J. Mater. Chem. 11, 1057 (2001).

28) M. Yoshizawa and H. Ohno: Chem. Commun., 1828 (2004).

29) S. Ueda, J. Kagimoto, T. Ichikawa, T. Kato and H. Ohno : Adv. Mater. 23, 3071 (2011).

30) S. Taguchi, T. Matsumoto, T. Ichikawa, T. Kato and H. Ohno : Chem. Commun. 47, 11342 (2011).

31) Y. Ito, Y. Kohno, N. Nakamura and H. Ohno: Chem. Commun. 48, 11220 (2012).

32) S. Taguchi, T. Matsumoto, T. Ichikawa, T. Kato and H. Ohno : Chem. Commun. 48, 5271 (2012).

33) T. Ichikawa, T. Kato and H. Ohno: J. Am. Chem. Soc. 134, 11354 (2012). 